is paved with good intentions, the writer makes it clear to her reader that desires and intentions alone are not enough to save the soul.

Having analyzed all the above, we come to the conclusion that L. Ulitskaya's novel «Daniel Stein, interpreter» is a novel in the center of which a number of important issues of existential order and the problem of life and death takes one of the dominant places in this series. Without a doubt, the most important conclusion of this book, in the context of the studying issue, is that death is as natural stage of life as any other (childhood, youth, maturing). You don't need to be afraid of this, on the contrary, you need to remember it. From the author's point of view, all mundane life is a preparation for this event.

\title{
References:
}

1. Ulitskaya, L. (2011). Daniel Stein, interpreter. Moscow: Eksmo.

\section{ENGLISH LANGUAGE TERMINOLOGICAL SYSTEM: PROBLEMS DEFINITION AND CLASSIFICATION OF TERMS}

\section{Inna Pylypenko ${ }^{1}$}

DOI: https://doi.org/10.30525/978-9934-26-002-5-16

With the growth of human knowledge and the development of ideas, as well as their change, the number of words in the language increases. Each new scientific discovery needs a name as a means of expressing a logical idea of the concept. This process also causes numerous changes in the meanings of existing words. English, like any other language, adapts to a wide variety of definition needs. The vocabulary of the language determines the possibilities for the expression of certain concepts or objects for their precise and expressive definition. The lack of definition of a known concept in language is one of the biggest obstacles to its transmission in language. Usually, these obstacles are overcome by creating a new word or borrowing a word from another language. Such replenishment of vocabulary occurs constantly, crystallizing in words all that has been deposited in the public consciousness. Each area of life and knowledge is characterized by its range of names, which should be mastered by everyone who deals with them. The need for names is an elementary condition for the accuracy of the language itself.

\footnotetext{
${ }^{1}$ Bila Tserkva National Agrarian University, Ukraine
} 
The formation of modern terminology of the English language begins with time Chaucer. In his work «Treatise on the astrolabe» Chaucer first used the terms declination, ecliptic, latitude, longitude, meridian, zodiac in the sense in which they are still used. He also introduced into use, in addition to Greek and Latin, the Arabic terms nadir, zenith, azimuth. With the Renaissance and the development of science, which tried to separate from church, a large number of terms appeared in European languages. Preferable some of them were either borrowed from classical languages or formed on the basis borrowing wordforming elements. With the spread of book printing, the emergence schools and the growth of general literacy most of the borrowed lexicon needed a popular explanation. The first dictionaries appeared, in which Latin terms were transmitted by means of their own vocabulary, as well as dictionaries of so-called difficult, incomprehensible words. These were the predecessors of explanatory dictionaries; their vocabulary was of a mixed nature, with the exception of dictionaries of jurisprudence, which gave rise to terminological dictionaries.

Problems of terminology were deeply studied by such linguists as G.O Vinokur, A.A Reformatsky, O.S Akhmanova, V.P Danilenko, N.Z. Kotelova, S.V Grinev and others. Most researchers admit that terminology one of the main stylistic features of the scientific style, informative core of vocabulary of languages of science. The term is usually understood linguistic means of expression of a special concept. O.S. Akhmanova defines the term as a «word or phrase of a special (scientific, technical, etc.) language, which is created, obtained or borrowed for the exact expression of special concepts and designations of special objects» [2, p. 95-96]. V.P Danylenko also adheres to the view that «a term is a word (or phrase) of a special field of application, which calls a special concept» [3, p. 11-13]. A short glossary [6] gives the following definition of the word «Term»: A term (Latin Terminus «border, end») is a special word or a phrase adopted in a particular professional field and used in special conditions. The term is a verbal definition of a concept that is part of the system of concepts of a particular field of professional knowledge. Approximately the same definitions of terminology are found in foreign dictionaries of linguistic terms. Thus, in the dictionary of J. Maruso [7] terminology is defined as a system of terms used to express concepts inherent in this science. Each term is based on the definition of the reality it denotes, so that the terms are an accurate and at the same time concise description of the object or phenomenon. Each branch of knowledge operates with its own terms, which are the essence of the terminological system of this science.

When defining the term emphasize its functional and semantic side, because the term according to the requirements defined for it must refer to one concept. V.I. Karaban defines the term as a linguistic sign that represents a concept special, professional field of science or technology. He believes that 
scientific and technical terms are an essential component of scientific and technical texts [4, p. 54]. A.Ya. Kovalenko gives the following definition of the term: the term is an emotionally neutral word or phrase, which is used to accurately express the concepts and names of objects [5, p. 257]. I.V. Arnold uses the term to describe a word or phrase that is used for a clear expression of a concept specific to any field of knowledge, production or culture, and which serves the communicative needs in this area human activity [1, p. 81].

Many authors who have studied the terms have tried to classify these units. For example, M.I. Mostovy [8, p. 191-192] divides terminology into nomenclature and professionalism. Nomenclature is a set of special termsnames, which are used in a separate professional field. M.I. Mostovy [8, p. 192] distinguishes another type of term - a trademark or paronym. Its application is associated with the study of the motivation of the behavior of a prospective buyer. In the process of paronym formation, both psychological factors of assumptions, beliefs and semantic, analog and other features of the word involved are taken into account. When naming an object or type of services, the combinational features of sound and meaning of the form, mixed imitation processes are taken into account. The trademark is intended for a wide range of the population, and therefore a well-known commonly used word is included in the composition of the mark. I.V. Arnold [1, p. 83] pays attention to the fact that the set of terms of a particular industry forms its terminological system. The scope and content of the concept reflected in the term is fixed in the literature and are part of the system of professional knowledge in this field. For a word to become a term, it must have a definition in the literature. This definition is called a definition. But this does not mean that every term has one definition. Different authors, using the same term, give it a slightly different definition.

The reason for this diversity is that the definition corresponds to different ones tasks of one or another direction in linguistics and reflects the formation of the author to the subject. Thus, we can conclude that the term is a word or phrase that serves to express the concept or names of the subject and is accepted in the relevant professional field and used in special circumstances. The term as a word of a special field of knowledge reflects the results of experience and practical human activity, captures professional and scientific knowledge about the properties of the described object. Through the definition, the term reveals essential features and expresses a special concept in a special field.

\section{References:}

1. Arnol'd, I. V. (1991). Osnovy nauchnykh issledovaniy $v$ lingvistike [Fundamentals of scientific research in linguistics]. Uchebnoe posobie. Moskow: Vyssh. shkola. (in Russian) 
2. Akhmanova, O. S. (1957). Ocherki po obshchey i russkoy leksikologii [Essays on general and Russian lexicology]. Moskow: Uchpedgiz. (in Russian)

3. Danilenko, V. P. (1991). Semanticheskaya struktura spetsial'nogo slova i ee leksikograficheskoe opisanie [Semantic structure of a special word and its lexicographic description]. Sverdlovsk: RAO. (in Russian)

4. Karaban, V. I. (2001). Pereklad anglijskoyi naukovoyi i texnichnoyi literatury [Translation of English scientific and technical literature]. Uchbovyj posibnyk. Vinnycya: Nova Knyga. (in Ukrainian)

5. Kovalenko, A. Ya. (2001). Zagalnyj kurs naukovo-texnichnogo perekladu [General course of scientific and technical translation]. Uchbovyj posibnyk. Kyiv: Knygha. (in Ukrainian)

6. Grynchyshyn, D. (ed) (1999). Korotkyj tlumachnyj slovnyk ukrayinskoyi movy [A short explanatory dictionary of the Ukrainian language]. Kyiv. (in Ukrainian)

7. Maruzo, Zh. (1960). Slovar' lingvisticheskikh terminov [Dictionary of linguistic terms]. Moskow: Izdatel'stvo inostrannoy literatury. (in Russian)

8. Mostovyj, M. I. (1993). Leksykologhija anghlijsjkoji movy [Lexicology of the English language]. Pidruchnyk dlja studentiv in-tiv i fak. inozemnoji movy. Kharkiv: Osnova. (in Ukrainian)

\section{FRENCH PHRASEOLOGICAL UNITS: PECULIARITY OF TRANSLATION}

\section{Nadiya Popel ${ }^{1}$}

DOI: https://doi.org/10.30525/978-9934-26-002-5-17

Integration of European countries, migration, expanding contacts with business partners abroad and the spread of modern information technologies require modern man mobility and communication skills in different languages, acquaintance with the cultures of other peoples, awareness of native culture and language, the desire to find themselves in such a diverse world.

The problem of high-quality training of specialists in the sphere of translation necessitates a detailed study of communication theory aspects, the functioning of language units, the improvement of translation models.

The study of the nature of phraseologisms is necessary to show the problem of the ratio of phraseological units in different languages for translation, to find interlingual universals for creating phraseological dictionaries, to develop the teaching of phraseological theory for future translators and teachers of French.

\footnotetext{
${ }^{1}$ State Agrarian and Engineering University in Podilia, Ukraine
} 